folk/ed. Derg, 2020; 26(2): 425-434

DOI: $10.22559 /$ folklor.1035

\title{
Tebriz'de Yayınlanan Azerbaycan Türkçesinde Bir Dergi "Dede Korkut Dergisi"
}

\author{
A Journal in Azerbaijan Turkish Published in Tabriz \\ "Dede Korkut Journal"
}

\section{Nabi Kobotarian(Azeroğlu)* Roghaiyeh Azizpour ${ }^{* *}$}

\begin{abstract}
$\ddot{O} z$
İran'da basın hayatı Kaçar Hanedanı padişahı olan Fethali Şah Kaçar zamanında ortaya çıktı. O dönem İran'daki matbaacılığın merkezi Tebriz olduğu bilinmektedir. Tebriz'den sonra diğer şehirlerde matbaalar kurulmuştur. İran İslam devriminden sonra Tebriz'de yayına başlayan Dede Korkut Dergisi Azerbaycan Türkçesinde ve Arap alfabesiyle İran'da yayınlanan ilk Türkçe dergiler arasında tarihe geçmiştir. Dergi birçok ilkleri beraberinde getirmiştir. Türk dili ve kültürünü hor gören Şah dönemi sonrası bu derginin ortaya çıkması İran’da yaşayan Türklerin özlüğüne dönüşünün bir simgesi olarak görülmektedir. Dönemin siyasi ve içtimai çalkantılar nedeniyle ne yazık ki bu dergi diğer dergiler gibi kısa ömürlü olmuş ve yirmi sayı çıktıktan sonra kapatılmıştır.
\end{abstract}

1359 H.Ş./1980-Ağustos 1361 H.Ş./1982 Nisan tarihleri arasında Dr. Hüseyin Feyzullahi'nin baş sorumluğunda çıkan Dede Korkut Dergisi'nin içeriği milli bilinci aş1lamak, milli kültürü korumak ve Azerbaycan Türkçesinin eğitim diline

Geliş tarihi (Received): 14.07.2019- Kabul tarihi (Accepted): 09.01.2020

Bu makale, R.Azizpour'un yüksek lisans tezinden yararlanılarak hazırlanmıştır.

*Niğde Ömer Halisdemir Üniversitesi. nabikobotarian@ohu.edu.tr. ORCID ID 0000-0002-0660-6746.

** Niğde Ömer Halisdemir Üniversitesi, Türk Dili ve Edebiyatı Bölümü, doktora öğrencisi. azizpurr@ohu.edu.tr. ORCID OD 0000-0003-4640-8186. 
çevirmek isteğigibi konular üzerinde yoğunlaşmıştır. Derginin adından da belli olduğu gibi milli edebiyat konuları ön plana çıkmaktaydı. Derginin öne çıkan önemli bir hususiyeti de milli edebiyat geleneğinde Dede Korkut, Oğuz Han, Tepegöz, Alpamış ve diğer ulusal karakterlerin ilk defa İran Türklerine tanıtması olmuştur. Bu çalışmada İran İslam Devriminden sonra Tebriz'de yayınlanan Dede Korkut Dergisi'nin tanıtılmasını amaçlanmıştır.

Anahtar sözcükler: Tebriz, Iran Türkleri, Dede Korkut dergisi

\begin{abstract}
The media in Iran emerged during the reign of Qajar Turks Sultan Feth Ali Shah Qajar. The center of printing in Iran was Tabriz and the first book, in Iran, was recorded in this city. After Tabriz, printing houses were established in other cities. Dede Korkut Journal which was published in Tabriz between 1980 and 1982. It was one of the first journals in Turkish published in Azerbaijan Turkish in Iran with Arabic alphabet. The publication of the journal in the city of Tabriz in Iran brought many firsts. After Shah Period, who despised Turkish language and culture, the emergence of this magazine is known as a symbol of the return of the Turks living in Iran to their own roots. Unfortunately, the journal was closed after twenty issues.

Dede Korkut Journal, which was published under the supervision of Dr. Feyzullahi, aimed to highlight the importance of national culture and the protection of the Azerbaijan Turkish language. The journal gave priority to national literature and local authors. Another significant feature of the journal is that it introduced national characters such as Dede Korkut, Oğuz Han, Tepegoz and other characters to the Iranian Turks for the first time in national literature. This study aims to the Dede Korkut Journal published in Tabriz.
\end{abstract}

Keywords: Tabriz, İran Turks, Dede Korkut journal

\title{
Giriş
}

İran'da basın hayatı Kaçar Türkleri padişahı Feth Ali Şah Kaçar zamanında başladı. O dönem İran' daki matbaacılığın merkezi Tebriz olduğu bilinmektedir. İlk basılan kitabın bu şehirde olduğu tarihte kaydedilmişti (Serdariniya, 2002: 35). Tebriz'den sonra diğer şehirlerde matbaalar kurulmuştur. 1920 kadar Tebriz'de 101 ünvan gazete ve dergi yayımlandı. İlk gazeteler devlet eliyle basılsa da ilk bağımsız gazete Azerbaycan aydınları tarafından İstanbul'da basıldı. Ahter (اختر) Gazetesi bu dönemde İstanbul'da basılarak Tebriz'e gönderilmekteydi.

İran coğrafyasında edebiyat geleneğinin köklü bir geçmişi olmasına rağmen basın ve matbaacılık batı kültüründen alınmıştır. Eski zamanlarda kitaplar müstensihler vasıtasıyla çoğaltılıyordu. Matbaa makinesinin gelişiyle birlikte İran'da da müstensihlerin yerini makineler aldı. İran coğrafyasında basılan ilk kitaplar Tebriz'de taş basımı adını verdiğimiz yöntemle Fuzuli'nin gazelleri olmuştur. İran'da basın hayatı Kaçar padişahı Fethali Şah Kaçar zamanında başlar. İlk matbaa onun zamanında İran' da kullanılmıştır.

İran'da matbaa ve matbaacılığın merkezi Tebriz olduğu bilinmektedir. İran'da ilk basılan kitabın bu şehirde olduğu tarihe kaydedilmiştir (Serdariniya, 2002: 35). Tebriz'den sonra 
diğer şehirlerde de matbaalar kurulmuştur. Tebriz eskiden beri bir kültür merkezi olmuş Osmanlı topraklarına yakınlığından dolayı matbaanın İran'a geldiği ilk merkez olmuş ve birçok dergi ve kitap bu şehirde basılarak İran'a yayılmıştır.

Tarihi yönüyle de Tebriz kenti Ak Koyunlu, Kara Koyunlu ve El Denizli'ler hanedanı zamanında İran'ın başkent olmuştur. Şemseddin El Deniz 1146 yılında Selçuklu imparatorluğu döneminde Tebriz'de El Deniz devletini kurdu. Nahcivan, Gence gibi büyük yerleri kapsayan bu devlet daha sonra Harezmşah devletine karıştı. Zeki Velid Togan'ın belirttiği gibi Kara Koyunlu ve Ak Koyunlu Azerbaycan'daki hâkimiyeti devri bu ülkenin en parlak ve Türk nüfusunun en çok bulunduğu devirdir (Togan, 1981: 38). Bu kent 1230 da Moğol İlhanlıları, Kara Koyunlu ve Ak koyunlu ve en sonunda 1500 yılında Safevilerin başkenti olmuştur. Tebriz'de minyatür okulu 14. yüzyıl başında İlhanlılar tarafından kurulmuş ve 16. yüzyıl ortalarına değin devam etmiştir. İbn-i Battûte ve Hamdullah Kazvini Tebriz ve çevresinde Türk varlığından bahsetmişlerdir (Köprülü, 1989: 24). Günümüze dek Tebriz ister kültürel ister siyasi yönüyle İran'ın önemli kentlerinden biri olmuştur. Daha sonra Tahran'ın başkent olması kültürel yönüyle Tebriz'den ileriye geçse de Tebriz son döneme kadar siyasi ve içtimayi yönüyle her zaman ön planda olan bir merkez olmuştur.

\section{1. İran'da basın hayatı ve basın devreleri}

İran'da tarihi ve siyasi gelişmeleri göz önünde bulundurduğumuzda yayın devrelerini şu şekilde sıralayabiliriz: Meşrutiyet öncesi (1850 - 1905), Meşrutiyet dönemi (1906 - 1920), Pehlevi dönemi (1921 - 1978), İslam devrimi dönemi (1979 - 2019). Bu dönemlerin her birinde siyasi nedenlerden dolayı çeşitli sansür ve kısıtlamalar görülmektedir. Hatta bu sebeplerden dolayı ülke dışında basılıp gizlice ülkeye getirilen yayınlar da olmuştur. Buna örnek olarak Ahter gazetelerinin İstanbul'da basılıp Tebriz'e gönderildiğini verebiliriz (Azizpour, 2019: 4).

İran'da ilk gazete $1837^{\prime}$ de taş basımı yöntemiyle Kaçar hakimi Muhemmed Ali Şah zamanında aylık şeklinde “Ahbar-i Vakayi Dar’ül Hilafeyi Tehran” ( تـ طـر ان

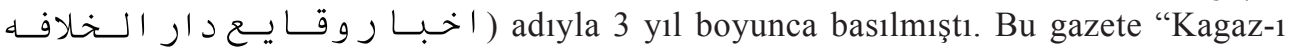

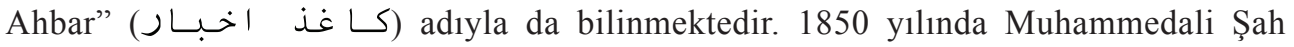

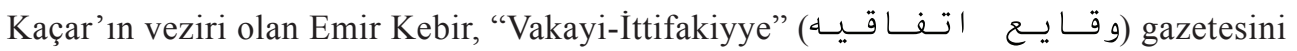
çıkarttı. Haftalık şeklinde yayınlanan bu gazete bir kaç defa ad değiştirdi ve günümüzde İran gazetesi adıyla yayımını sürdürmektedir.

Gazete, dergi ve haftalık yayımlar başkentten sonra Nasirittin Şah Kaçar zamanında Şiraz'da "Fars" adıyla yayımlanmıştr. Tebriz'de "Naseri" ve "Milleti”, İsfahan' da ise "Farheng” adında yayımlanmıştı. Bu dönemde İran'ın diğer kentlerinde de matbaacılık geliştirildi. 1920'ye kadar Tebriz'de 101 ünvan gazete ve dergi yayımland. İlk gazeteler devlet eliyle basılsa da ilk bağımsız gazete Azerbaycan aydınları tarafından İstanbul'da basıldı. Ahter ( (اخـــ Gazetesi bu dönemde İstanbul'da basılarak Tebriz'e getirilmekteydi (Serdariniya, 2002: 52). 


\section{Dede Korkut Dergisi'nin yayına başlaması}

1359 H.Ş./1980-Ağustos, 1361 H.Ş./1982 Nisan tarihleri arasında çıkan Dede Korkut Dergi'si Azerbaycan Türkçesiyle İran'da yayınlanan ilk Türkçe dergilerden biri olarak tarihe geçmiştir. ${ }^{2}$ Şah döneminde baskılar sonucunda Azerbaycan Türkçesinin yasaklanması İran sahasında Türkçe (Azerbaycan Türkçesinde) yazar okur sayısı yok diyecek kadar düşüktü. Devletin yasaklamasına paralel olarak halkın arasında "Türkçe zor bir dil, yazıp okunması imkansız bir dil” telkinler de gene devlet organları tarafindan yapılmaktaydı. İran'da Türkçenin sökülüp atılması için yürütülen bu siyaset aslında Rıza Şah döneminden başlamıştı.

Dede Korkut Dergisi'nin İran'ın Tebriz kentinde yayımlanması önemli bir siyasi ve kültürel olaydır. Türk kültürünü hor gören Şah dönemi sonrası bu derginin ortaya çıkması İran'da yaşayan Türklerin yeniden özüne dönüşünün bir simgesi olmuştur. Bu dergiden sonra Tahran'da yayın hayatına giren Varlık Dergisi değerli bilim insanı Dr. Cavad Heyet teşebbüsüyle İran'da yaşayan Türklerin bir diriliş haykırışı olmuştur. Varlık Dergisi merkezde yayınlanma olanaklarından faydalanarak günümüze kadar sürüp gelmiştir. Ancak Dede Korkut ve Köroğlu ve diğer dergiler başkent imkânlarına uzak kalması ve Tebriz'de yaşayan Türklerin milli hassasiyetinin ortaya çıkmasıyla devlet tarafından uzun yaşama imkânı bulamamış ve iki yıl çıktıktan sonra kapanmak zorunda kalmıştır. Tabi bunların yanında maddi nedenleri de belirtmemiz gerekmektedir. O dönem Türkçenin yazılışı ve okunuşu yaygın olmadığı için derginin okuyucu sayısı belirli bir kesimi aşmamaktaydı. Derginin tüm masrafları Dr. Hüseyin Feyzullahi üzerine olduğundan dergiye yardım ve destekleyici bulunmadığından bir müddet dergi kendi yağıyla kavrulsa da zaman içinde masraflar karşılanamamıştır. Devrim şartlarının yanı sıra İran-Irak savaşı da ekonomik döngüsünü zor dönmeye başlatmıştı. Dr. Feyzullahi bu dönemde parmağındaki nişan yüzüğünü de satarak derginin giderlerini karşılamaya çalışmıştır. Ancak daha fazla bu iş yürümemişti ve dergi ikinci yılını göremeden 20. sayısının ardından durdurulmuştur.

1945-1946 Güney Azerbaycan Milli Hökümeti Şah'ın ordusu tarafından yıkıldıktan sonra Azerbaycan Türkçesi yasaklandı ve basılan kitaplar yakılarak yok edildi. Bu olay Nazilerin kitap yakma olayıyla birlikte tarihe geçmiştir. Bunun yanı sıra Türkçe yazan yazarlar tutuklanıp idam edilmiştir. Bu kültürel soykırımdan sonra İran sahasında Türkçe yazar okurlarında bir kopma olmuş toplumun düşünürlerinin yeniden yetişmesi ve ortaya ürün koymaları 40 yıla yakın bir süre gerektirmiştir.

İran şahı Rıza Şah babası gibi Türkçe’nin yok edilme politikasını tüm şiddetiyle sürdürmüştür. Bu dönemde iki elin parmak sayılarını geçmeyen düşünürler milli edebiyattan esinlenerek Türkçe eserler vermeye başladılar. Ali Tebrizli, Ali Kemali, Mehemed Ali Farzane, Bulut Karaçorlu ve Dr. Hüseyin Feyzullahi gibi düşünür ve yazarlar zorluklar içinde Türkçeyi yaşatmaya çalışmışlar. Nitekim Dr. Feyzullahi bu yüzden 10 yıl hapse maruz kalmıştı.

1979 İran İslam devrimiyle birlikte kültürel yönden yeni umutlar yeşermeye başladı. Bu dönemde birçok dergi (Azerbaycan Türkçesinde) çıkmaya başladı. Devrimden sonra Dr. Feyzyllahi siyasi mahpuslar gibi hapisten çıkarıldı. Daha önce uğrunda hapis yattığı kitap ve dergileri çıkarmaya başladı. Dede Korkut Dergisi ve Köroğlu Dergisi bu dönemın parlak 
dergilerinden sayılmaktaydı. Ne yazık ki bu dergiler kısa süren siyasi refahlığın ürünleri olmuşlar. Önceki rejimin kalıntıları ve Türk (Azerbaycan Türkü) varlığını inkâr edenler yine işbaşına geçtiğinden siyasi ve kültürel özgürlük kısa sürmüştür.

Dede Korkut Dergisi'nin çıkış amaçlarından biri edebî yazıların okuyucularla buluşturulmasının yanı sıra dönemin kültürel ve edebi faaliyetlerin haberlerini yaymak olmuştur. O döneme kadar İran'daki Türkçe yayınlar birkaç kitap ile sınırlıydı. Ali Tebriz'nin çıkardığg Aliağa Vahid'in Gazelleri, Fuzuli'nin Gazelleri en çok okunan kitaplar idi. Bu kitaplar şahsî çabalar sonucunda çıkmış az baskı sayısı ile kısıtlı bir okuyucu kitlesine ulaşmaktayd1. 1979 devriminden sonra İran İslam Cumhuriyeti anayasasında kültürel hakların verilmesi konusunda anayasada madde olmasına rağmen devrimden sonra bu madde hiçbir zaman yürürlüğe konulmadı. Eski sistemin kalıntıları İslamî sistemin içinde yerini muhafaza ederek Azerbaycan Türkçesinin yok edilmesi politikası farklı bir mecrada yürütülmüştür.

Dede Korkut Dergisi'nin sorumlusu Dr. Hüseyin Feyzullahi Vahid (Ulduz) ile görüşmemizde bu derginin yayım amacının Azerbaycan milli kültürü ve benliğini korumak, gelecek nesillere milli kültürü aktarmak olduğunu belirtmiştir. ${ }^{4}$

\section{Dede Korkut Dergisi'nin şekil bilgileri}

Dede Korkut Dergisi'nin kapak sayfaları Türk kültürü ve edebiyatı ile ilgili şahıslara ayrılmıştır. Kimi zaman tarihî şahsiyetler kimi zaman da çağdaş portrelere yer verilmiştir. Büyük yazıyla Dede Korkut adının önünde derginin sayısı yer almaktadır. Hemen altında "Edebi Mecelle" yazısı ve onun altında derginin yıl, sayı, ay ve fiyatı yazılmaktadır. Derginin genel çizgisi edebi konular içermekteydi.

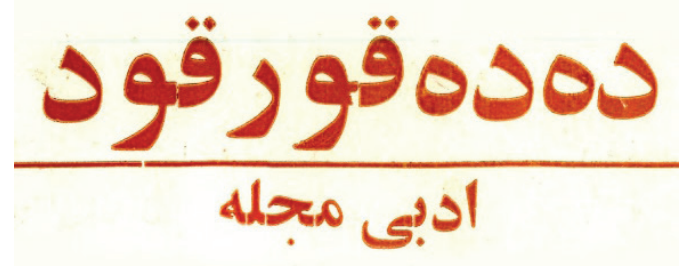

Şekil 1: Dede Korkut Edebi Mecelle

Derginin birinci sayısının kapağına Tebriz'in ünlü âşıklarından olan Dr. Feyzullahi'nin babası Âşık Ali Feyzullahi’nin resmi koyulmuştur. 


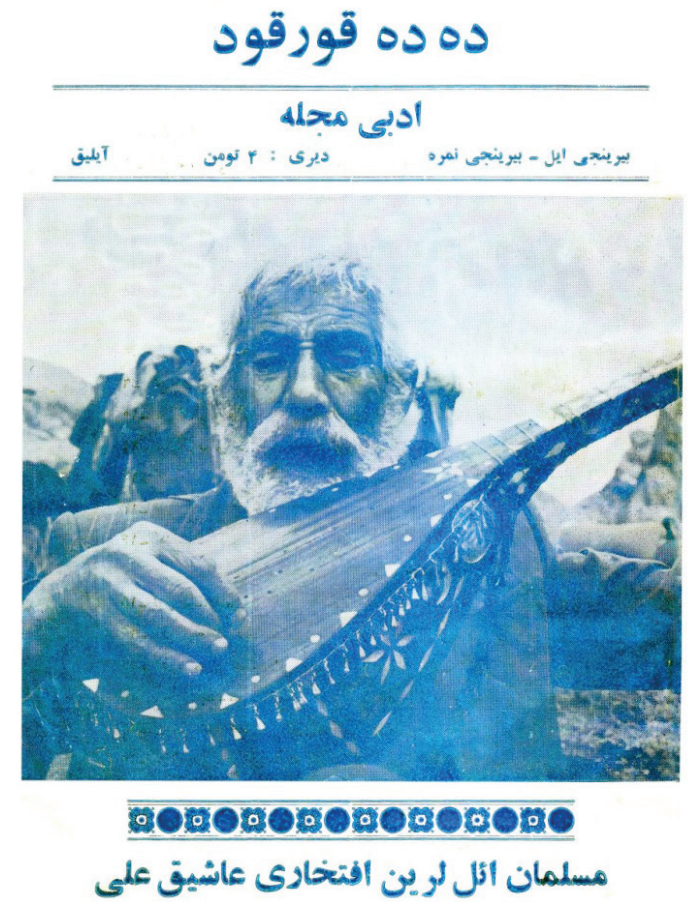

Resim: 2 - Dede Korkut Dergisi'nin birinci saylsının kapă̆g

\section{Dede Korkut Dergisi'nin yazar kadrosu}

Dede Korkut Dergisi çok geniş bir yazar kadrosuna sahip değil idi. Dönemin siyasi nedenlerinden dolayı Türkçe bir dergide Türkçe yazı yazmanın devlet organları tarafından nasıl karşılaşacağı meçhuldü. Nitekim devrimin ilk aylarından sonra bu gibi faaliyetler siyasi suç olarak değerlendirilmeye başlandı. Derginin baş sorumlusu Dr. Hüseyin Feyzullahi (Ulduz) şah döneminde hapishanede kalmasına rağmen devrimden sonra da siyasi baskılara maruz bırakılmış birçok kültürel faaliyetini durdurmak mecburiyetinde kalmıştır.

Tebriz'de Dr. Feyzullahi ile görüşmemizde bu bilgileri vermiştir:

“Dede Korkut Dergisi’nin yazar kadrosunu birkaç kişiden oluşmaktaydı. Yazarlar genelde takma ad ile yazılar göndermekteydiler. Birkaç takma ad da kendime aittir. Yazarlar siyasi görüşlerini belirtmemek için farklı takma ad ile yazılar yazmaktaydı. Devlet tarafından takibe alınmamak için yazarlar farklı takma adlar kullanmaktaydı”.

Derginin çekirdek kadrosunda üç kişi bulunmaktaydı. Dr. Hüseyin Feyzullahi Vahid (Ulduz)", Aliriza Zihak (Ağçaylı)» ve Hemid Ahmedzade (Telimhanlı)! Bunların yanısıra Güney Azerbaycan'ın ünlü yazarları da dergide yazılar yazmışlar. Hüseyin Mehemmedzade Sedik (Düzgün), Semed Serdariniya, Hesen Mecidzade (Savalan), Mirza İbrahimov, Hekime Buluri, Süleyman Rüstem, Balaş Azeroğlu, Bahtiyar Vahabzade gibi ünlü yazarların yazısı Dede Korkut Dergisi'nde yazıları bulunmaktadır. Bahtiyar Vahabzade'nin Âşık Ali Feyzullahi’ye yazdığı mektuba derginin on sekizinci sayısında yer verilmişstir. 


\section{Dede Korkut Dergisi'ndeki yazılar}

Derginin birinci sayısında Balaş Azeroğlu'nun “Ana Dili” adlı şiirini görmekteyiz. Bu şiirde, ana dili yasaklandığ için hapise atılmış bir kişiyle onu hapse atan kişi arasında karşılıklı konuşmaya yer verilmiştir. Şiirde Azerbaycan Türkçesinin yasak olduğu, okullarda çocukların başka dilde eğitim aldıkları işlenmektedir. Bu konular derginin diğer sayılarında da yer verilmektedir: "Ana Dilime", Mehemmed Gence, sayı, 2, s. 20. ‘'Bize Şahname ne Gerek", Ülker, sayı, 6, s. 4, benzer konular işlenmektedir. Bu örneklerde gördüğümüz gibi İran'da Azerbaycan Türkçesi'nin resmileşmesi, ana dilde eğitimin olması gerektiği vurgulamaktadır. Dede Korkut Dergisi'nin amaç ve istekleri bu şiirlerde yansıtılmıştır.

Edebi konuların nazım ve nesir türünün tümünün dergide bulabiliriz. Makale, hikâye, şiir, hiciv, çocuk edebiyatı, âşık edebiyatı, folklor yazıları en çok görünen yazı türleri olarak karşımıza çıkmaktadır. Dergideki konular genel olarak milli düşünce içerikli, milli duygulara hitap eden konulardır. Bu konular düz yazılar ve şiirlerde işlenmiştir. Şehriyar'ın yeni yazılan şiiri, Dede Korkut Dergisi’nin eki olarak dördüncü sayıda dağıtılmıştır.

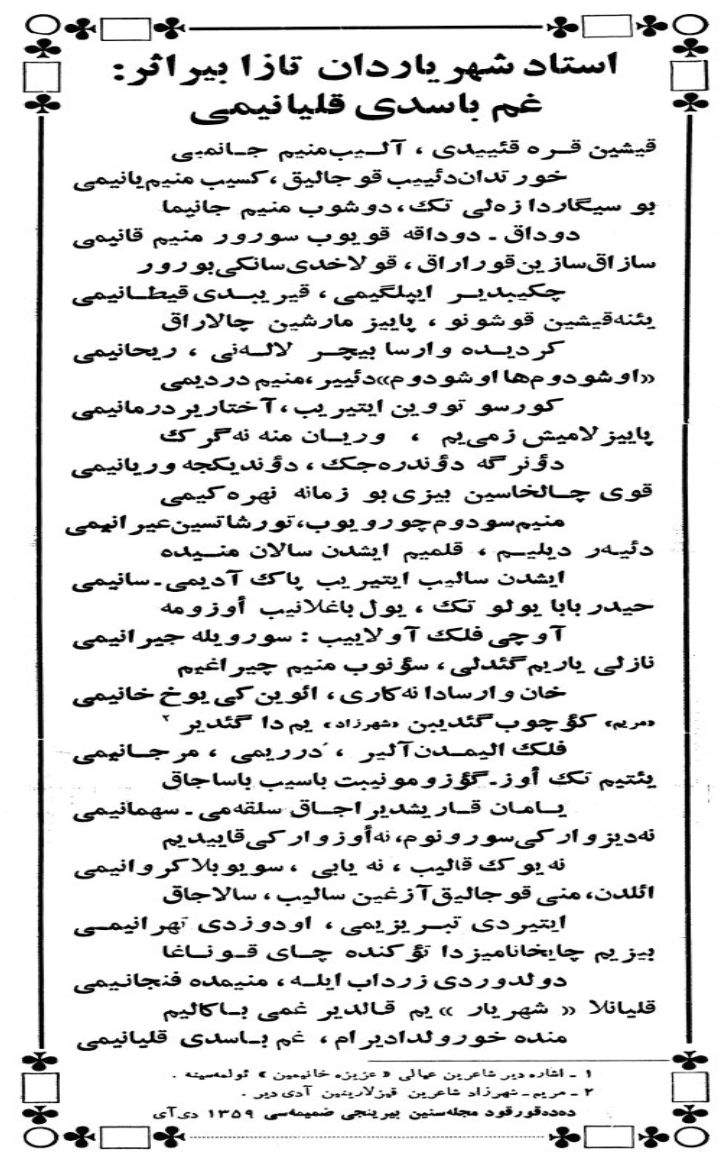

Resim 3- Dede Korkut Dergisi'nin dördüncü saylsında Mehemmed Hüseyin Şehriyar'ın yeni bir şiiri derginin eki olarak basıldi. 


\section{6. Âşı şiirleri}

Dede Korkut Dergisi'nin milli edebiyatı ön planda tutan bir dergi olduğunu, âşık’destanları ve şiirlerine yer verdiğini görmekteyiz. Milli edebiyatın önemli yapıtı olan destan ve hikâyeler ozanların halefi sayılan âşıklar tarafından günümüze ulaşmıştır. İran'da Âşıkların sözlü destanlarını toplayarak yazıya geçiren bilim insanları milli benliği ve milli kimliği korumayı amaçlamışlardır. Dede Korkut Dergisi'nin sorumlusu Dr. Feyzullahi Vahid Tebriz'de yaşayan ünlü Âşık'Ali'nin oğludur ve bu yüzden milli edebiyat ve âşık’şiirleriyle iç içe olmuştur. Derginin bir diğer yazarı ise Aliriza Bey Ağçaylı Hoy ve Tebriz âşık hikâyelerini derleyip toplamıştır ve dergide bu hikâyelere yer verilmiştir.

Âşıklar Türk dilini nesilden nesile aktarmış, Türk kültürünün önemli bölümünün taşıyıcı görevini üstlenmişlerdir. Tebriz âşıklarının dilinde duru ve arı Türkçeyi bulmak mümkündür. Âşıklar Türkçenin ses yapısına uygun olan hece sayısıyla şiirlerini söylerler, bu yönüyle Türkçeyi en duru şeklinde kullanan kişiler âşıklardır (Kobotarian, 2013: 45).

Dede Korkut Dergisi'nde Türk milli kültüründe önemli yeri olan âşılara önemle yer verilmiştir. Dergi İran'da yaşayan âşıkların hayatını ve eserlerini tanıtmakla beraber Türk dünyası âşıklarına ve eserlerine yer vermişti. Türkiye'den Âşık’ Veysel ve Âşı İhsani, Kazakistan'dan Cambul Cabayev gibi Türk dünyasının önde gelen âşıklarına yer verilmiştir.

Dede Korkut Dergisi'nin on dördüncü sayısında sayfa 34-35 aralığında Âşsk’ Veysel'in hayatı ve şiirlerine yer verilmiştir. "Türkiye Muasır Âşıklarından Âşı|’ Veysel” adlı yazıda âşığın çocukluğunda hastalığa yakalanarak gözlerini kaybettiğini ve 14 yaşında babasının ona bir saz vererek saz çalmaya başladığını kaydedildikten sonra "Sazıma" adlı şiirine yer verilmiştir.

\section{Sonuç ve değerlendirme}

1980 yılından aylık olarak Tebriz'de yayına başlayan Dede Korkut Dergisi Azerbaycan Türkçesiyle İran'da yayınlanan ilk Türkçe dergilerden biri olarak İran Türklerinin kültürel hayatlarında önem kazanmıştır. Dergi, İran'da Azerbaycan Türkçesinde Arap alfabesiyle çıkmaktaydı. O döneme kadar İran’da yayılan Türkçe yayınlar birkaç kitap ile sınırlıydı. Derginin çıkış amaçlarından biri edebî yazıların okuyucularla buluşturulmasının yanı sıra dönemin kültürel ve edebi faaliyetlerin haberlerini yaymaktır.

Dr. Feyzullahi'nin baş sorumluğunda çıkan Dede Korkut Dergisi'nin içeriği milli kültüre vurgu, Azerbaycan Türkçesinin İran sınırları içinde yaşatılması ve korunması olmuştur. Derginin adından da anlaşılacağı üzre millî edebiyat ürünleri, millî konulu yazıların ön plana çıktığını görmekteyiz. Derginin öne çıkan bir hususiyeti de millî edebiyat geleneğinde Dede Korkut, Oğuz Han, Tepegöz ve diğer karakterleri ilk defa İran Türklerine tanıtması olmuştur. O zamana dek bu millî ögeler İran Türklerinde tanıtılmamıştır. Dr. Feyzullahi’nin çıkardığı Dede Korkut Dergisi bu yönüyle bir ilk olmuştur. İran Türklerini bu değerlerle tanıştırmak Dede Korkut'un en önemli görevi olmuştur. Nitekim bu dergiden sonra diğer Türk dergilerinin de ortaya çıktığını görmekteyiz.

Dede Korkut Dergisi çıktığı zaman İran Türkleri’nin İran coğrafyasında inkâr ve tahkîr dönemine denk gelmekteydi. Pehleviler döneminde İran'da Türk kimliğini ortadan kaldırma 
politikası tüm devlet organları vasıtasıyla yürütülmekteydi. O dönem Türkçe (Azerbaycan Türkçesi) konuşan okul çocuklarını cezalandırmak, halk arasında Türkçenin zor bir dil olduğunu, çeşitli asimile araçlarla Türk milli kültürünü yok ettirme politikalarının uygulandığını görmekteyiz. Derginin millî edebiyatı ön planda tutan bir çizgide olarak, âşık destanları ve şiirlerine yer verdiğini görmekteyiz. Bu değerlerin yükseltmesini amaçlayan dergi halk arasında rağbet görse de devlet organları tarafından hoş karşılanmamıştı.

Dede Korkut Dergisi’ndeki yazılarda genel olarak milli düşünce içerikli, milli duygulara hitap eden konular olduğunu görmekteyiz. Bu konular düz yazılar ve şiirlerde işlenmiştir. Bunların yanında milli edebiyatımızın yaratan âşıkların şiirlerine de yer verilmiştir. Bu dergi uzun süre yaşamına devam etmese de diğer dergilere yol göstericilik ve 1şık tutmayı başarmıştır. Nitekim Varlık Dergisi'nin kadrolarında da bu derginin yazarlarını görmekteyiz.

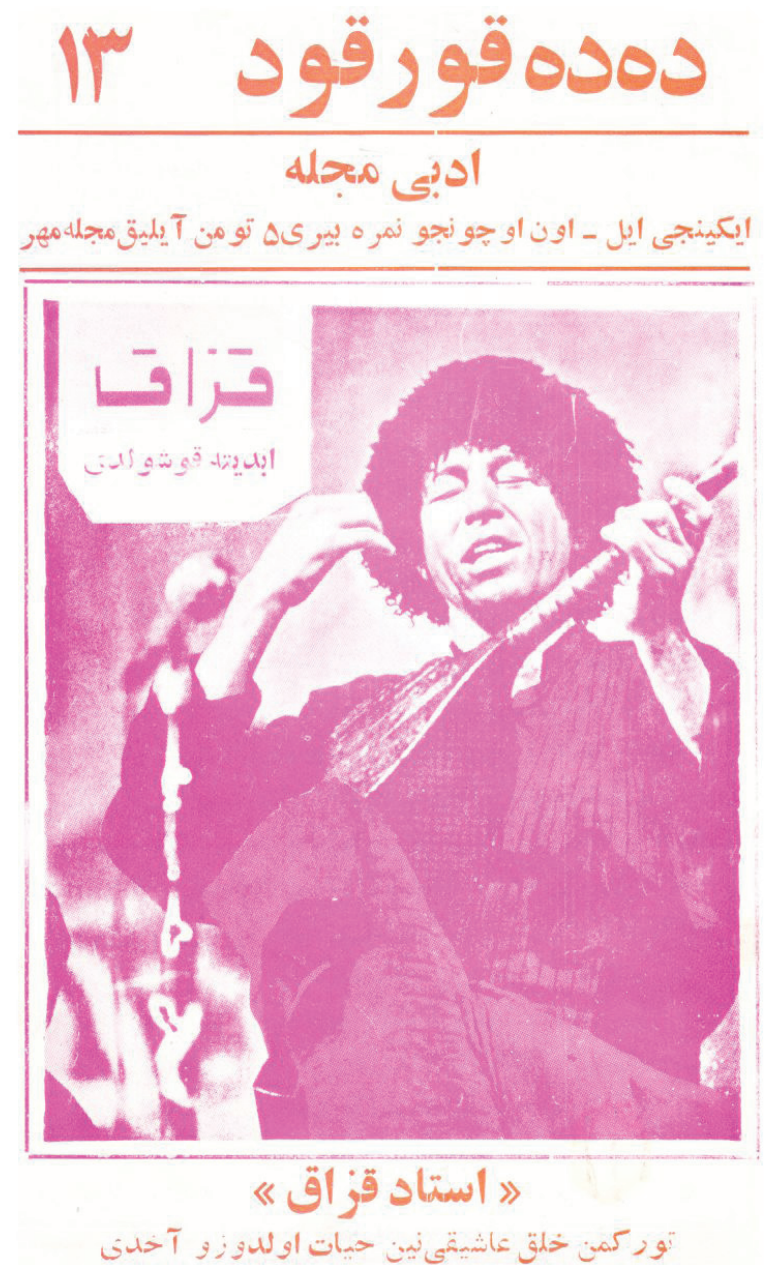

Resim 4: Dede Korkut Dergisi’nin on üçüncü saylsının kapă̆ı 


\section{Notlar}

1 Feth Ali Şah Kaçar, 1797'de Ağa Mehemmed Han Kaçar öldüğünde tahta geçti. Onun döneminde matbaa gibi birçok yenilikler görülmektedir. 1834 te İsfahan'da öldü.

212 Aralık 1945 - 12 Aralık 1946 yılları arasında, Seyyid Cafer Pişeveri önderliğinde Güney Azerbaycan Türkleri, Azerbaycan Milli Hükümeti kuruldu. Milli hükümet sayesinde Güney Azerbaycan Türkleri kendi ana dillerine eğitim hakkı kazandılar. Azerbaycan Türkçesi resmi devlet dili olarak ilan edildi. Tebriz Üniversitesi kuruldu ve ekonomide büyük adımlar atıldı. Ne yazık ki bu hükümetin ömrü bir seneden fazla olmadı ve şahın ordusu tarafından kaldırıldı. Türkçe kitaplar yakıldı ve kültürel bir soykırım başlatıldı.

3 11.07.2018 tarihinde Tebriz'de görüşmemizde kayda alınmıştır.

4 11.07.2018 de Tebriz'de görüşmemizde belirtilmiştir.

\section{Kaynaklar}

Azizpour, R. (2019). Iran'da yayılanan Dede Korkut Dergisi üzerine bir inceleme (1980-1982). Yayınlanmamış Yüksek Lisans Tezi. Niğde Ömer Halisdemir Üniversitesi Sosyal Bilimler Enstitüsü, Avrasya Araştırmaları Anabilim Dalı. Niğde.

Sedr Haşimi, M. (1328). تاريخ جرايد و مجلات ايلان(Tarix-i Cerayid vä Mäcällat İran). İsfahan.

Köprülü, M. F. (1989). Saz şairleri. Ankara: Akçă̆.

Kobotarian, N. (2013a). Tebriz âşıklık geleneği ve âşıł edebiyatı. Adana: Karahan.

Serdariniya, S. (2002). تبريز شهر اولينها Tebriz şsehr-i evvelinha (Farsça). Tebriz: Azerbaycan Sanat ve Kültür.

Togan, Z. V. (1981). Bugünkü Türkili ve Türkistan ve yakın tarihi. İstanbul: Enderun. 